\title{
PEWARNAAN PADA GRAF BINTANG SIERPINSKI
}

\author{
Siti Khabibah \\ Departemen Matematika, FSM Undip \\ khabibah.undip@gmail.com
}

\begin{abstract}
This paper discuss about Sierpinski star graph $S S_{n}$, which its construction based on the Sierpinski triangle. Vertex set of Sierpinski star graph is a set of all triangles in Sierpinski triangle; and the edge set of Sierpinski star graph is a set of all sides that are joint edges of two triangles on Sierpinski triangle. From the vertex and edge coloring of Sierpinski star graph, it is found that the chromatic number on vertex coloring of graph $S S_{n}$ is 1 for $n=1$ and 2 for $n \geq 2$; while the chromatic number on edge coloring of graf $S S_{n}$ is 0 for $n=1$ and $3.2^{n-2}$ for $n \geq 2$.
\end{abstract}

Keyword : Sierpinski star graph, Sierpinski triangle, edge, vertex, chromatic number

\begin{abstract}
ABSTRAK. Pada makalah ini dibahas mengenai graf bintang Sierpinski $S S_{n}$ yang dikonstruksi berdasarkan segitiga Sierpinski. Himpunan titik dari graf bintang Sierpinski adalah himpunan semua segitiga pada segitiga Sierpinski; sedangkan himpunan sisi dari graf bintang Sierpinski adalah himpunan semua sisi yang merupakan persekutuan dua segitiga pada segitiga Sierpinski. Dari pewarnaan titik dan pewarnaan sisi, diperoleh bilangan kromatik untuk pewarnaan titik pada Graf $S S_{n}$ adalah 1 untuk $n=1$ dan 2 untuk $n \geq 2$; sedangkan bilangan kromatik untuk pewarnaan sisi pada Graf $S S_{n}$ adalah 0 untuk $n=1$ dan $3.2^{n-2}$ untuk $n \geq 2$.
\end{abstract}

Kata kunci : Graf bintang Sierpinski, segitiga Sierpinski, titik, sisi, bilangan kromatik

\section{PENDAHULUAN}

Salah satu kajian menarik dalam fraktal adalah pembahasan mengenai segitiga Sierpinski. Segitiga Sierpinski merupakan fraktal yang serupa dengan dirinya atau disebut dengan self similar fractal. Untuk membangun segitiga Sierpinski diperlukan sebuah segitiga sama sisi yang selanjutnya dibagi menjadi 4 buah segitiga yang kongruen dengan skala setengah dari segitiga sebelumnya, selanjutnya segitiga yang dihasilkan secara berulang dibagi lagi menjadi 4 buah segitiga dengan skala setengahnya untuk semua segitiga kecuali untuk segitiga yang tepat berada di tengah, yang dalam paper ini disebut segitiga pusat (triangle center). Pada tahun 1997 Klavzar dan Milutinovic memperkenalkan graf Sierpinski $S(n, k)$ yang merupakan generalisasi dari masalah Tower Hanoi (Klavzar dan Milutinovic,1997). Sifat-sifat graf Sierpinski dapat dijumpai dalam (Teguia dan Godbole, 2006). Selain graf Sierpinski, terdapat graf Sierpinski 
gasket $S_{n}$ yang bentuknya identik dengan segitiga Sierpinski, dengan himpunan titik dan sisi dari graf $S_{n}$ adalah titik sudut dan sisi segitiga-segitiga dari segitiga Sierpinski. Klavzar (2008) menulis mengenai pewarnaan pada graf Sierpinski dan Sierpinski gasket, sedangkan Jacovac dan Klavzar (2009) membahas mengenai pewarnaan titik, sisi, dan pewarnaan total pada graf Sierpinski dan graf Sierpinski gasket. Selain graf Sierpinski yang berupa segitiga, ada juga graf Sierpinski yang berupa bujursangkar. Graf ini dikenal dengan nama graf Square Sierpinski. Pewarnaan pada graf Square Sierpinski dibahas dalam (Xue, Zuo dan Li, 2015).

Pada makalah ini, akan dibahas mengenai salah satu jenis graf yang dikonstruksi berdasarkan segitiga Sierpinski, yaitu graf bintang Sierpinski. Graf ini dinotasikan dengan $S S_{n}$, dan dibatasi hanya untuk $n$ berhingga. Bagian pertama makalah membahas mengenai konstruksi graf $S S_{n}$ beserta penghitungan banyaknya titik dan sisi. Selanjutnya, pewarnaan titik dan sisi pada graf ini dibahas pada bagian kedua. Dari pewarnaan titik dan sisi tersebut diperoleh bilangan kromatik untuk pewarnaan titik dan sisi pada graf $S S_{n}$.

\section{GRAF BINTANG SIERPINSKI (Sierpinski Star Graph)}

Secara geometris graf bintang Sierpinski $S S_{n}$ dengan $n \geq 1$ merupakan graf yang dikonstruksi dari segitiga Sierpinski. Himpunan titik dari graf bintang Sierpinski $S S_{n}$ merupakan himpunan semua segitiga dari segitiga Sierpinski hasil iterasi ke- $n$, dan titik yang mewakili segitiga pusat disebut titik pusat (center vertex); sementara itu, himpunan sisinya merupakan himpunan semua sisi yang merupakan persekutuan dari dua segitiga dalam segitiga Sierpinski. Banyaknya titik dan sisi dari graf $S S_{n}$ dinotasikan dengan $\left|V_{n}\right|$ dan $\left|E_{n}\right|$. Banyaknya titik dan sisi dari graf $S S_{n}$ disajikan pada Proposisi 1. Untuk memberikan ilustrasi, pada gambar berikut disajikan segitiga Sierpinski hasil iterasi ke-4 dan graf Bintang Sierpinski iterasi ketiga $\left(S S_{4}\right)$. 


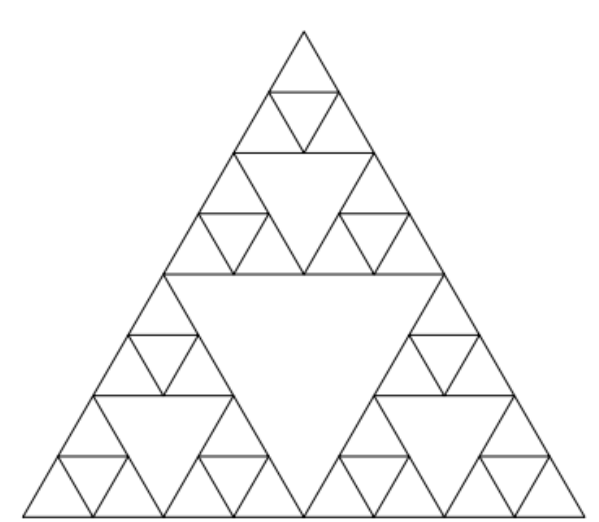

Gambar 1a. Segitiga Sierpinski iterasi ke-4

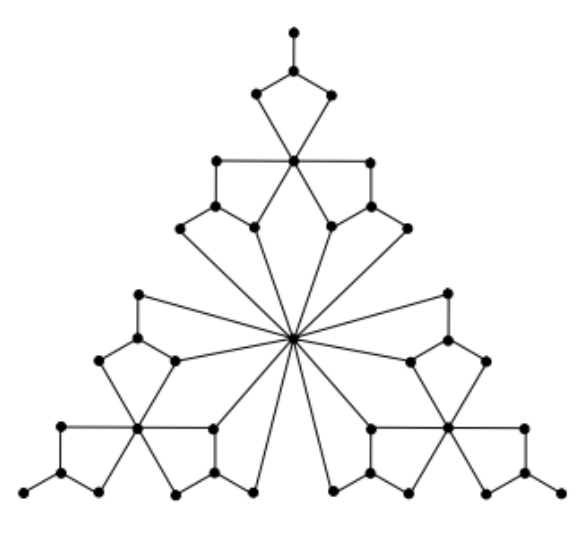

Gambar 1b. Graf $S_{4}$

Proposisi 1. Graf bintang Sierpinski $S S_{n}$ mempunyai $\frac{1}{2}\left(3^{n}-1\right)$ titik untuk $n \geq 1$ dan $\sum_{i=0}^{n-2} 2^{i} \cdot 3^{n-1-i}$ sisi untuk $n \geq 2$.

Bukti. Karena Graf $S S_{n}$ dikonstruksi dari segitiga Sierpinski dengan banyaknya titik pada $S S_{n}$ diperoleh dari jumlah segitiga pada $S_{n}$, maka untuk $n=1$ banyaknya titik pada $S_{n}$ adalah 1 karena hanya terdapat satu segitiga pada segitiga sierpinski untuk iterasi pertama. Untuk iterasi selanjutnya banyaknya titik pada graf $S S_{n}$ diperoleh dari persamaan

$$
\left|V_{n+1}\right|=3\left|V_{n}\right|+1 \text { untuk } n \geq 1 \text {. }
$$

Karena $\left|V_{1}\right|=1$, maka

$$
\begin{aligned}
\left|V_{n+1}\right| & =\sum_{i=1}^{n} 3^{n-1} \\
& =\frac{1}{2}\left(3^{n+1}-1\right) .
\end{aligned}
$$

Oleh karena itu $\left|V_{n}\right|=\frac{1}{2}\left(3^{n}-1\right)$ yang berarti banyaknya titik Graf Bintang Sierpinski hasil iterasi ke- $n$ adalah adalah sebanyak $\frac{1}{2}\left(3^{n}-1\right)$.

Selanjutnya, banyaknya sisi pada graf bintang Sierpinski $S S_{n}$ berpadanan banyaknya sisi pada segitiga Sierpinski yang merupakan persekutuan dari dua segitiga pada segitiga Sierpinski (yang selanjutnya disebut sisi persekutuan). Karena hanya ada satu segitiga untuk $n=1$, maka tidak terdapat sisi persekutuan sehingga banyaknya sisi pada $S S_{1}$ adalah nol. Untuk $n=2$ ada empat segitiga 
kongruen dan segitiga pusat menyinggung ketiga sisi segitiga yang lain. Jadi, terdapat 3 sisi persekutuan yang berarti jumlah sisi pada $S S_{2}$ adalah 3 . Untuk selanjutnya, banyaknya sisi persekutuan pada segitiga Sierpinski hasil iterasi ke $(n+1)$ adalah 3 kali banyaknya sisi persekutuan pada iterasi ke- $n$ ditambah dengan banyaknya sisi persekutuan dari segitiga pusat, yang berjumlah 2 kali lipat dari iterasi sebelumnya. Oleh karena itu, banyaknya sisi pada $S S_{n}$ diperoleh dari persamaan

$$
\left|E_{n+1}\right|=3\left(\left|E_{n}\right|+2^{n-1}\right) \text { untuk } n \geq 1 \text {. }
$$

Karena $\left|E_{1}\right|=0$, maka

$$
\begin{gathered}
\left|E_{2}\right|=3\left(\left|E_{1}\right|+2^{1-1}\right)=3 \\
\left|E_{3}\right|=3\left(3+2^{1}\right) \\
\left|E_{4}\right|=3\left(3\left(3+2^{1}\right)+2^{2}\right) \\
\vdots \\
\left|E_{n+1}\right|=3^{n}+2.3^{n-1}+2^{2} \cdot 3^{n-2}+\cdots+2^{n-1} \cdot 3 \\
\left|E_{n+1}\right|=\sum_{i=0}^{n-1} 2^{i} \cdot 3^{n-i}
\end{gathered}
$$

Jadi, $\left|E_{n}\right|=\sum_{i=0}^{n-2} 2^{i} \cdot 3^{n-1-i}$, yang berarti banyaknya titik graf Bintang Sierpinski hasil iterasi ke- $n$ adalah adalah sebanyak $\sum_{i=0}^{n-2} 2^{i} \cdot 3^{n-1-i}$ untuk $n \geq 2$.

\section{PEWARNAAN PADA GRAF BINTANG SIERPINSKI}

Pada paper ini pembahasan mengenai pewarnaan pada Graf $S S_{n}$ meliputi pewarnaan titik dan sisi. Untuk pewarnaan titik menggunakan algoritma Welch and Powell yang mendahulukan titik dengan derajat terbesar. Selanjutnya derajat maksimum titik dari suatu graf $G$ dinotasikan dengan $\Delta(G)$. Dua teorema yang terkait dengan pewarnaan titik pada graf secara umum diberikan pada teorema berikut:

Teorema 1. ( Deo, N., 1994) Suatu graf G tidak memiliki sikel yang panjangnya ganjil jika hanya jika $G$ dapat diwarnai dengan dua warna. 
Teorema 2. ( Deo, N., 1994) Bilangan kromatik dari graf G tidak dapat lebih satu dari derajat maksimum titik-titik di $G$.

Dalam paper ini bilangan kromatik untuk pewarnaan titik dan sisi pada $S S_{n}$ dinotasikan dengan $\chi\left(S S_{n}\right)$ dan $\chi^{\prime}\left(S S_{n}\right)$.

Pertama-tama akan dikaji mengenai pewarnaan titik pada $S S_{n}$. Untuk $S S_{1}$ hanya terdapat satu warna karena banyaknya titik $S S_{1}$ adalah 1 atau dengan kata lain $\chi\left(S S_{1}\right)=1$. Selanjutnya dapat dibuktikan bahwa bilangan kromatik untuk pewarnaan titik graf $S S_{n}$ adalah 2 untuk $n \geq 2$.

Teorema 3. Untuk $n \geq 2$, bilangan kromatik untuk pewarnaan titik graf bintang Sierpinski adalah $\chi\left(S S_{n}\right)=2$.

Bukti. Untuk $n=2$ graf $S S_{n}$ identik dengan graf bintang dengan banyaknya titik adalah 4 dan terdapat satu titik berderajat 3 serta 3 titik berderajat 1 . Oleh karena itu jumlah warna minimum yang bisa diterapkan adalah 2. Sedangkan untuk $n \geq 3$, graf $S S_{n}$ tidak memiliki sikel dengan panjang ganjil, menggunakan Teorema 1 maka diperoleh graf $S S_{n}$ dapat diwarnai dengan dua warna. Jadi terbukti bahwa $\chi\left(S S_{n}\right)=2$ untuk $n \geq 2$.

Sebelum dibahas mengenai pewarnaan sisi pada graf $S S_{n}$ terlebih dahulu diberikan sebuah teorema terkait dengan pewarnaan sisi dikenal sebagai teorema Vizing sebagai berikut

Teorema 4. Untuk setiap graf $G$, berlaku $\Delta(G) \leq \chi^{\prime}(G) \leq \Delta(G)+1$.

Teorema Vizing tersebut digunakan dalam pembuktian teorema mengenai pewarnaan sisi pada graf $S S_{n}$. Untuk $n=1$ graf $S S_{n}$ hanya terdiri atas satu titik dan tidak mempunyai sisi. Jadi, bilangan kromatik pada pewarnaan sisi graf $S S_{n}$ adalah nol $\left(\chi^{\prime}\left(S S_{1}\right)=0\right)$. Akan ditunjukkan bahwa untuk $n \geq 2$ bilangan kromatik untuk pewarnaan sisi graf $S S_{n}$ adalah $3.2^{n-2}$, yang merupakan derajat maksimum titik graf $S S_{n}$. 
Teorema 5. Untuk setiap $n \geq 2$, bilangan kromatik untuk pewarnaan sisi graf bintang Sierpinski adalah $\chi^{\prime}\left(S S_{n}\right)=3.2^{n-2}$.

Bukti. Untuk $n=2$ graf $S S_{n}$ identik dengan graf bintang dengan 4 titik dan derajat maksimum titiknya adalah 3. Jadi, jumlah warna minimal yang dapat diaplikasikan adalah sebanyak 3. Selanjutnya untuk $n=3$, titik pusat dari $S S_{3}$ merupakan satu-satunya titik dengan derajat terbesar yaitu 6 yang berarti derajat maksimum titik dari $S S_{3}$ adalah 6. Karena tidak ada titik lain yang berderajat 6 , maka $\chi^{\prime}\left(S S_{3}\right)=6$. Pada graf $S S_{n}$ derajat maksimum titik menunjukkan jumlah sisi pada titik pusat graf $S S_{n}$ yaitu sejumlah $3.2^{n-2}$, dengan titik pusat merupakan satu-satunya titik yang mempunyai derajat maksimum. Dengan demikian, banyaknya warna minimal yang diaplikasikan pada graf $S S_{n}$ adalah sebanyak 3. $2^{n-2}$. Jadi terbukti bahwa $\chi^{\prime}\left(S S_{n}\right)=3.2^{n-2}$.

Ilustrasi mengenai hasil pewarnaan titik dan sisi pada graf $S S_{4}$ disajikan pada gambar berikut.

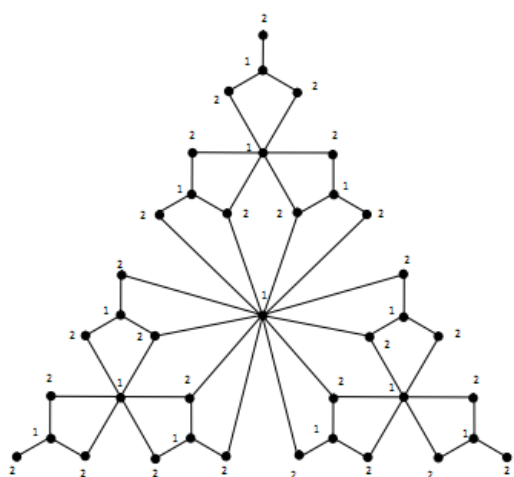

Gambar 2a. Pewarnaan titik graf $S S_{4}$

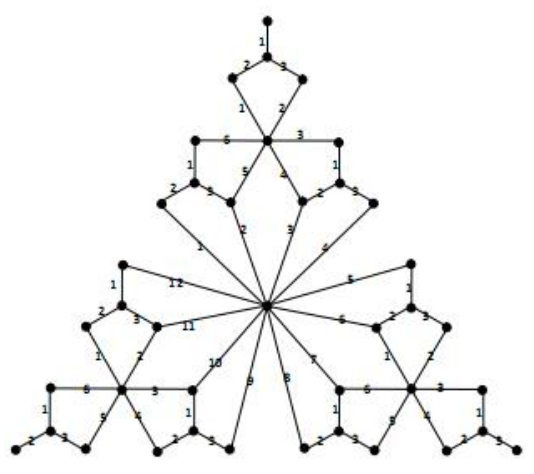

Gambar 2b. Pewarnaan sisi graf $S S_{4}$

\section{KESIMPULAN}

Graf bintang Sierpinski merupakan graf yang serupa dengan dirinya atau self similar. Banyaknya titik dan sisi dari graf ini bisa diperoleh menggunakan fungsi rekursif. Untuk bilangan kromatik pada pewarnaan titik diperoleh nilai yang sama, yaitu 2, kecuali pada graf $S S_{1}$. Sementara itu, bilangan kromatik pada pewarnaan sisi sama dengan derajat maksimum titik. 


\section{DAFTAR PUSTAKA}

Deo, N., Graph Theory with Application to Engineering and a Computer Science. Prentice-Hall International, Inc., New Delhi, 1994.

Jakovac, M. dan Klavžar, S., Vertex-, Edge-, and Total-Coloring of Sierpińskilike Graphs, Discrete Math., 309 (2009), 1548-1556.

Klavzar, S., Coloring Sierpinski Graphs and Sierpinski Gasket Graphs, Taiwanese Journal of Mathematics, 12(2) (2008), 513-522.

Klavžar, S., Milutinović, U., Graphs $S(n, k)$ and a Variant of the Tower of Hanoi Problem, Czechoslovak Math. J., 47(122) (1997), 95-104.

Teguia, A.M. dan Godbole, A.P., Sierpinski Gasket Graphs and Some of Their Properties, Australas. J. Combin., 35 (2006), 181-192.

Xue, B., Zuo, L. dan Li, G., Coloring the Square of Sierpinski Graphs, Graphs and Combinatorics, 31(5) (2015), 1795-1805. 
